\title{
Comparing methods for measuring phytoplankton biomass in aquaculture ponds
}

\author{
Yi-Kuang Wang ${ }^{1, *}$, Pei-Yu Chen ${ }^{1}$, Hans-Uwe Dahms ${ }^{2,3}$, Shinn-Lih Yeh ${ }^{4}$, \\ Ying-Jer Chiu ${ }^{4}$
}

\author{
${ }^{1}$ Department of Ecoscience and Ecotechnology, National University of Tainan, 33, Sec. 2, Shu-Lin St., Tainan City 70005 , \\ Taiwan, ROC \\ ${ }^{2}$ Department of Biomedical Science and Environmental Biology, Kaohsiung Medical University, 100 Shih-Chuan 1st Road, \\ Kaohsiung City 80424, Taiwan, ROC \\ ${ }^{3}$ Department of Marine Biotechnology and Resources, National Sun Yat-Sen University, No. 70, Lienhai Road, \\ Kaohsiung City 80424, Taiwan, ROC \\ ${ }^{4}$ Mariculture Research Center, Fisheries Research Institute, the Council of Agriculture, 4 Haipu, Sangu village, Cigu District, \\ Tainan City 72442, Taiwan, ROC
}

\begin{abstract}
Algal biomass is important for aquaculture in terms of eutrophication, as a secondary metabolite threat, and as a food source for suspension feeders and benthos. In order to evaluate the applicability of an in situ FluoroProbe instrument, chlorophyll a ( $\mathrm{chl} a$ ) measured with this device was compared to chl a measured by a fluorometer and to algal densities and biovolumes determined by direct counts. Monthly surveys were conducted in 3 types of aquaculture ponds (tilapia, milk fish, and common orient clam) from October 2011 through April 2012 in the Cigu region of Tainan City, Taiwan. Results showed that green algae were the predominant phytoplankton group, followed by cyanobacteria, euglenoids, and diatoms. The 3 types of aquaculture ponds had wide ranges of chl $a, \mathrm{pH}$, salinity, turbidity, $\mathrm{PO}_{4}{ }^{-3}-\mathrm{P}$, and suspended solids. Chl $a$ measured by the FluoroProbe had significant regressions with chl a values measured by a fluorometer, and with algal densities and biovolumes determined by counting; however, when chl a was $>250 \mu \mathrm{g} \mathrm{l}^{-1}$, the correlation between the FluoroProbe and the fluorometer diminished. The difference in chl a reads between these 2 methods increased when chl a concentration exceeded $200 \mathrm{\mu g} \mathrm{l}^{-1}$. Of the 4 differently colored algal groups measured by the FluoroProbe, only the green and blue groups had significant regressions with their respective biovolumes, whereas the red and brown groups had no significant regression with their respective biovolumes. Our results show the applicability of the FluoroProbe in algal monitoring of aquaculture ponds, although caution is needed at higher chl a levels.
\end{abstract}

KEY WORDS: FluoroProbe $\cdot$ Phytoplankton $\cdot$ Fluorometer $\cdot$ Algal density $\cdot$ Chlorophyll a

\section{INTRODUCTION}

Aquaculture production can be positively or negatively affected by microalgal biomass (Zimba et al. 2001, Hemaiswarya et al. 2011, Anand et al. 2013, $\mathrm{Hu}$ et al. 2013). Algal primary production can be used by suspension feeders in the plankton (such as

\footnotetext{
${ }^{*}$ Corresponding author: ykwang@mail.nutn.edu.tw
}

zooplankton or larvae of fish and invertebrates) or from the benthic environment (e.g. bivalves or by epistrata feeders, such as fish, shrimps, or polychaetes) (Uddin et al. 2009, Li et al. 2015, Zhang et al. 2016). Algae may also cause problems in aquaculture (Paerl \& Tucker 1995, Alonso-Rodríguez \& Páez-Osuna 2003, Casé et al. 2008), as they may

() The authors 2016. Open Access under Creative Commons by Attribution Licence. Use, distribution and reproduction are unrestricted. Authors and original publication must be credited. 
deteriorate the cultures of farmed organisms by oxygen depletion at night or after death (Dahms 2014), and by producing toxins that threaten both the health of the cultured organisms and the health of consumers (Ettoumi et al. 2011, Florczyk et al. 2014). Algae may impart a bad smell and taste to aquaculture products (Zimba \& Grimm 2003, Smith et al. 2008, Green \& Schrader 2015). Due to the abovementioned problems, the measurement of biomass, density, and diversity of microalgae has become a critical issue in aquaculture management (Mischke 2014, Kurten \& Barkoh 2016, Pucher et al. 2016). However, algal measurements are often timeconsuming and require taxonomic expertise, which is not practical for farmers. The recent development of a fast, easy-operating, in situ measuring instrument, the FluoroProbe, has improved the aforementioned shortcomings of algal measurements (Beutler et al. 2002, Rolland et al. 2010).

Several studies have applied the submersible FluoroProbe in reservoirs and rivers (Leboulanger et al. 2002, Gregor \& Maršálek 2004, Gregor et al. 2005, Rolland et al. 2010, Catherine et al. 2012). These studies indicated that measurements made with a submersible FluoroProbe and the spectrophotometer method were similar at low chlorophyll a ( $\mathrm{chl}$ a) levels, whereas the FluoroProbe might underestimate chl $a$ at high ambient chl a levels (Gregor \& Maršálek 2004, Rolland et al. 2010). The above studies were conducted in environments with relatively low chl $a$. To date, no study has tested the FluoroProbe in aquaculture ponds, where relatively high chl a levels can be reached. Therefore, such an evaluation seems timely.

The objective of this study was to assess whether the FluoroProbe is applicable to the particular environmental conditions of aquaculture ponds, particularly to high densities of planktonic microalgae. Two approaches were taken: (1) to compare results of the FluoroProbe to that of a fluorometer; and (2) to compare the results of overall and individual algal groups measured by the FluoroProbe to algal density and biovolume measurements made by direct counting.

\section{MATERIALS AND METHODS}

\section{Study area}

The surveyed aquaculture ponds were situated in the Cigu region of Tainan City in southern Taiwan (Fig. 1). We investigated 3 common types of aquaculture ponds in this area, where the following products were raised: tilapia (Oreochromis spp.), milk fish Chanos chanos, and common orient clam Meretrix lusoria (hereafter simply 'clam'). Each aquaculture type had 3 ponds. A canal, connected to a water source for aquaculture ponds, was also surveyed to expand the range of algal levels. Tilapia ponds had water depths from 1.8 to $2.5 \mathrm{~m}$, areas from 0.3 to 0.7 ha, a density of about 12000 fish $\mathrm{ha}^{-1}$, and a growth period about 1 yr. Milk fish ponds had water depths from 0.7 to $1.2 \mathrm{~m}$, areas from 0.45 to $1.2 \mathrm{ha}$, densities of 7000 fish $\mathrm{ha}^{-1}$, and a growth period of

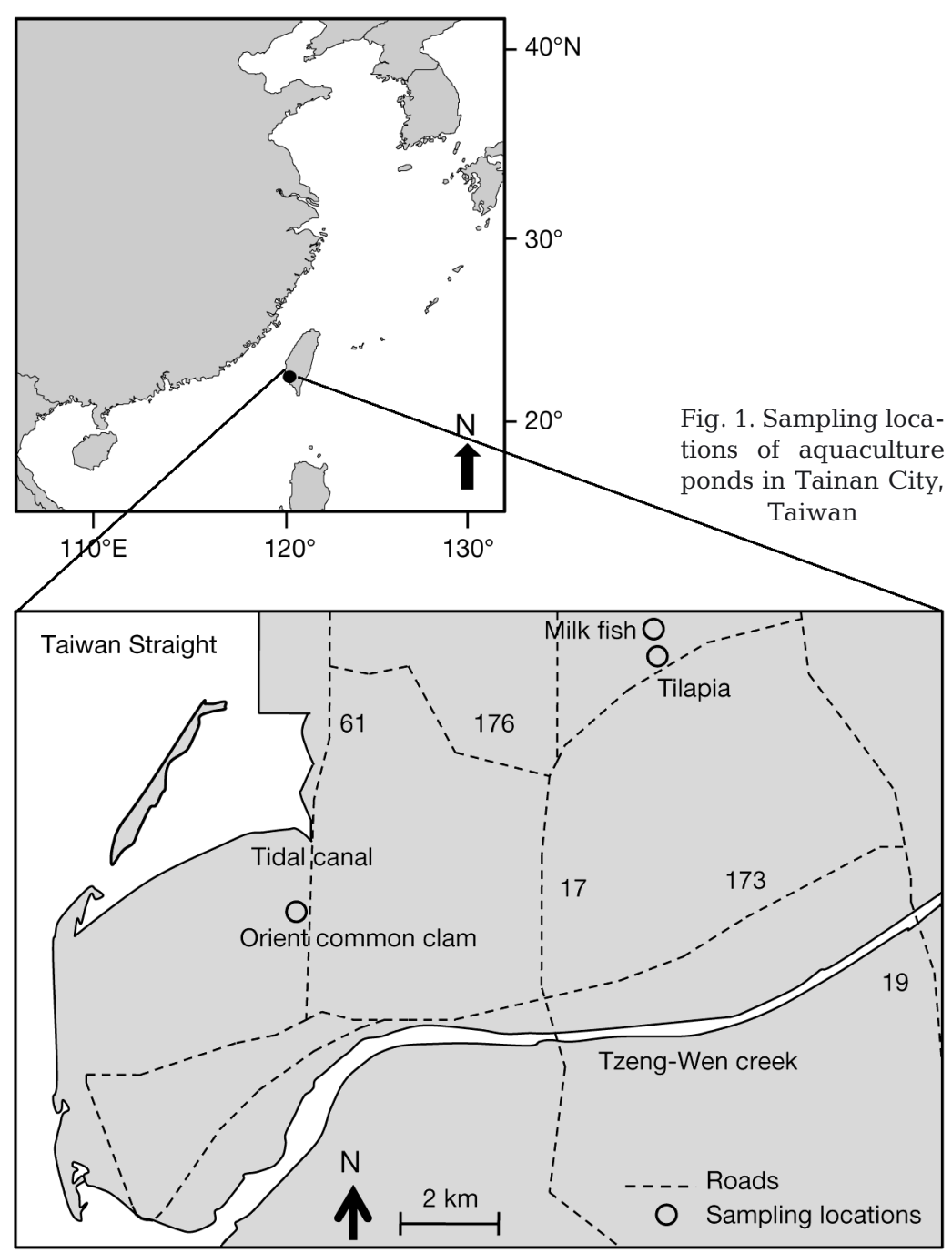


less than 1 yr. Clam ponds had a water depth of about $1.1 \mathrm{~m}$, areas from 1.6 to $4.8 \mathrm{ha}$, and a cultivating period of 6 mo to $1 \mathrm{yr}$. Water in the tilapia and milk fish ponds was not changed unless the water quality had severely deteriorated, whereas water in the clam ponds was flushed by the tides.

\section{Sampling and sample processing}

Samples were taken monthly from October 2011 to April 2012, when cultured organisms were harvested. Field water quality metrics, including water temperature, $\mathrm{pH}$, conductivity, and dissolved oxygen (DO), were measured with a multiprobe meter (YSI 556) and a DO meter (YSI DO 200). A Ruttner sampler (Hydro-Bios) was used to collect water at depths from 30 to $60 \mathrm{~cm}$. Each phytoplankton sample was $900 \mathrm{ml}$, and each chl $a$ and water chemistry sample was $300 \mathrm{ml}$. Phytoplankton samples were preserved with $5 \%$ Lugol's, whereas chl $a$ and water chemistry samples without preservatives were stored on ice in a dark container in the field.

A FluoroProbe instrument (bbe-Moldaenke) was used to measure chl $a$ and 4 algal groups in situ. The sensor of the FluoroProbe was lowered to $50 \mathrm{~cm}$ below the water surface, and values were read every $2 \mathrm{~s}$ (25 times). The data were initially stored within the FluoroProbe before statistics were applied as described below.

The FluoroProbe commonly measures fluorescence emitted by Photosystem II core pigments at $680 \mathrm{~nm}$ as chl a (Beutler et al. 2002). It also uses different fluorescent wavelengths to separate 4 major algal groups by their absorption maxima (Beutler et al. 2002). The green group, which is rich in chl $a$ and $b$, includes chlorophytes and euglenophytes, whereas the brown group, rich in xanthophylls, includes bacillariophytes, chrysophytes, and dinoflagellates (Rolland et al. 2010). The red group, rich in phycoerythrin, includes cryptophytes and red cyanobacteria, whereas the blue group, rich in phycocyanin, includes blue-green cyanobacteria (Rolland et al. 2010).

\section{Phytoplankton analysis}

Phytoplankton samples were concentrated to $50 \mathrm{ml}$ by the settling and decanting method in a refrigerator (Hötzel \& Croome 1999). The settling time was at least $6 \mathrm{~h}$ for every $1 \mathrm{~cm}$ of water column (Furet \& Benson-Evans 1982). For quantitative enumeration of algae, algal samples were fixed onto a slide using the syrup method (Stevenson 1984). Subsamples of phytoplankton of known volumes were added to $0.2 \mathrm{ml}$ of $10 \%$ syrup that covered a $22 \times 22 \mathrm{~mm}$ cover slip (Stevenson 1984), and then dried in the dark and sealed onto a slide by nail polish. Algal taxa were identified at $1000 \times$ magnification under a compound microscope (Olympus BX51) and then counted at $400 \times$. Biovolumes of algae were measured according to the shape measurements of Hillebrand et al. (1999). At least 300 natural units were recorded (Charles et al. 2002). For algal identification, Ding \& Li (1991), Carmelo (1997), and Yamagishi (1992) were consulted.

Chl a was analyzed according to the ethanol extraction method of the National Institute of Environmental Analysis (NIEA, Taoyuan, Taiwan; Protocol No. E509.01C). Chl a was concentrated on a filter paper of $1 \mu \mathrm{m}$ pore size and $47 \mathrm{~mm}$ in diameter (Whatman GF/C) by filtering $100 \mathrm{ml}$ of the pond water sample. The extraction was done by dissolving chl a on filter paper with $10 \mathrm{ml}$ of $99.5 \%$ ethanol in a centrifuge tube, which was further soaked in a $60^{\circ} \mathrm{C}$ water bath with periodic shaking for $30 \mathrm{~min}$. After extraction, the sample was centrifuged at $3500 \times g$ (13 min). An aliquot from the upper layer of the sample was used for measurements of chl a by a fluorometer (multipurpose, Turner).

\section{Water chemistry}

Four types of nutrients were measured in the laboratory: $\mathrm{NH}_{4}{ }^{+}-\mathrm{N}$ and $\mathrm{NO}_{3}{ }^{-}-\mathrm{N}$ were analyzed by the NOVA 60 water quality instrument (Merck), whereas $\mathrm{NO}_{2}^{-}-\mathrm{N}$ and $\mathrm{PO}_{4}{ }^{-3}-\mathrm{P}$ were analyzed by the Cintra 20 spectrophotometer (GBC). $\mathrm{NO}_{2}{ }^{-} \mathrm{N}$ was analyzed at $543 \mathrm{~nm}$ wavelength, and $\mathrm{PO}_{4}{ }^{-3}-\mathrm{P}$ was analyzed at $700 \mathrm{~nm}$ wavelength. Regression lines were established for $\mathrm{NO}_{2}{ }^{-}-\mathrm{N}$ and $\mathrm{PO}_{4}{ }^{-3}-\mathrm{P}$. Turbidity was measured with a turbidity instrument (TURB 355T, WTW). Suspended solids (SS) were measured by the NIEA drying method (NIEA W210.58A). These instruments were calibrated with standards supplied by their respective companies before measurements.

\section{Data analyses}

Chl $a$ and water quality variables among the 3 types of aquaculture ponds and the chl a:biovolume ratio of samples dominated by different algal phyla were statistically compared by 1-way 
Welch's ANOVA and the GamesHowell multiple comparison test because of variance heterogeneity (Field 2005; R package userfriendlyscience [https://cran.r-project.org/web/ packages/userfriendlyscience/index. html]). Variables except $\mathrm{pH}$ were log transformed to achieve normality. Relationships among chl a measured by the in situ FluoroProbe and the fluorometer for 3 types of ponds and all samples were assessed by linear regression (R package stats), whereas the relationships between chl a by the FluoroProbe and fluorometer and algal densities and biovolumes (all log transformed) were assessed by linear regression using the quadratic model $\left(y=a+b x+c x^{2}\right)$. To further understand the relationship between these 2 methods, Spearman rank correlations between ranges of chl a measured by a fluorometer ( $>$ or $<25,50,100,150,200,250,300 \mu \mathrm{g} \mathrm{l}^{-1}$ ) and corresponding chl a readings of the FluoroProbe were assessed. According to the aforementioned ranges, the paired differences of chl a by these 2 methods were analyzed by a 1-sample $t$-test (compared to 0). Relationships between chl a of algal groups by the in situ FluoroProbe and respective algal biovolumes (all log-transformed) were also assessed by linear regression using the quadratic model. Statistical analyses were conducted with $\mathrm{R}$ software (R Core Team 2015).

\section{RESULTS}

\section{Comparison among 3 types of aquaculture ponds}

Three types of aquaculture ponds differed in chl $a_{\text {, }}$ $\mathrm{pH}$, salinity, turbidity, $\mathrm{NO}_{2}{ }^{-}-\mathrm{N}$ and $\mathrm{PO}_{4}{ }^{-3}-\mathrm{P}$ (Table 1). These measured environmental variables covered wide ranges of environmental conditions. Tilapia ponds had the highest chl $a$, followed by milk fish ponds and clam ponds. Clam ponds had the highest salinity, followed by milk fish ponds and tilapia ponds. Dominant algal genera in tilapia ponds included Chlorella sp. (40.9\%) and Euglena sp. (25\%), while dominant algal genera in milk fish ponds included Euglena (20.7\%), Oscillatoria (16.5\%), Chlorella (10.8\%), and Nitzschia (10.2\%). Dominant algal genera in clam ponds were Euglena (25.6\%), Oscillatoria (20.4\%), Chorella (13.4\%), and Nitzschia $(12.6 \%)$.

\section{Comparison between submersible FluoroProbe and fluorometer}

Chl a measured by the fluorometer had a significant regression with that by the FluoroProbe $(y=$ $1.889+1.217 x, F_{1,61}=486.17, \mathrm{p}<0.001$, adjusted $\mathrm{R}^{2}=$ 0.887; Fig. 2a). When different ranges of chl a were analyzed, correlation coefficients decreased with increasing chl a (Table 2). When chl a was $>250 \mu \mathrm{g} \mathrm{l}^{-1}$, the correlations were not significant. Further analyses of chl a differences between the fluorometer and FluoroProbe showed that the mean differences were not significantly greater than 0 when ranges of chl a were $<200 \mu \mathrm{g} \mathrm{l}^{-1}$, but the means differed from 0 when chl a was smaller or greater than $250 \mu \mathrm{g}^{-1}(t=$ $2.22, \mathrm{p}=0.032 ; t=4.93, \mathrm{p}<0.001$; respectively). Samples with chl $a>250 \mu \mathrm{g} \mathrm{l}^{-1}$ were often dominated by green algae and/or euglenophytes. The 3 types of aquaculture ponds also showed significant regressions between the fluorometer and FluoroProbe chl a (tilapia: $F_{1,16}=20.91, \mathrm{p}<0.001$, adjusted $\mathrm{R}^{2}=0.539$; milk fish: $F_{1,19}=56.85, \mathrm{p}<0.001$, adjusted $\mathrm{R}^{2}=0.736$; clam: $F_{1,15}=42.01, \mathrm{p}<0.001$, adjusted $\mathrm{R}^{2}=0.719$ ).

\section{Comparison between FluoroProbe measurements and algal densities}

Algal cell densities had significant regressions with chl a measured by FluoroProbe and fluorometer $(y=$ $0.729+3.257 x-0.167 x^{2}, F_{2,60}=72.13, \mathrm{p}<0.001$, adjusted $\mathrm{R}^{2}=0.697 ; y=1.501+2.230 x-0.334 x^{2}, F_{2,60}$ $=44.96, \mathrm{p}<0.001$, adjusted $\mathrm{R}^{2}=0.586$; respectively; Fig. 2b). Algal biovolume densities also had significant regressions with chl a measured by the Fluoro- 


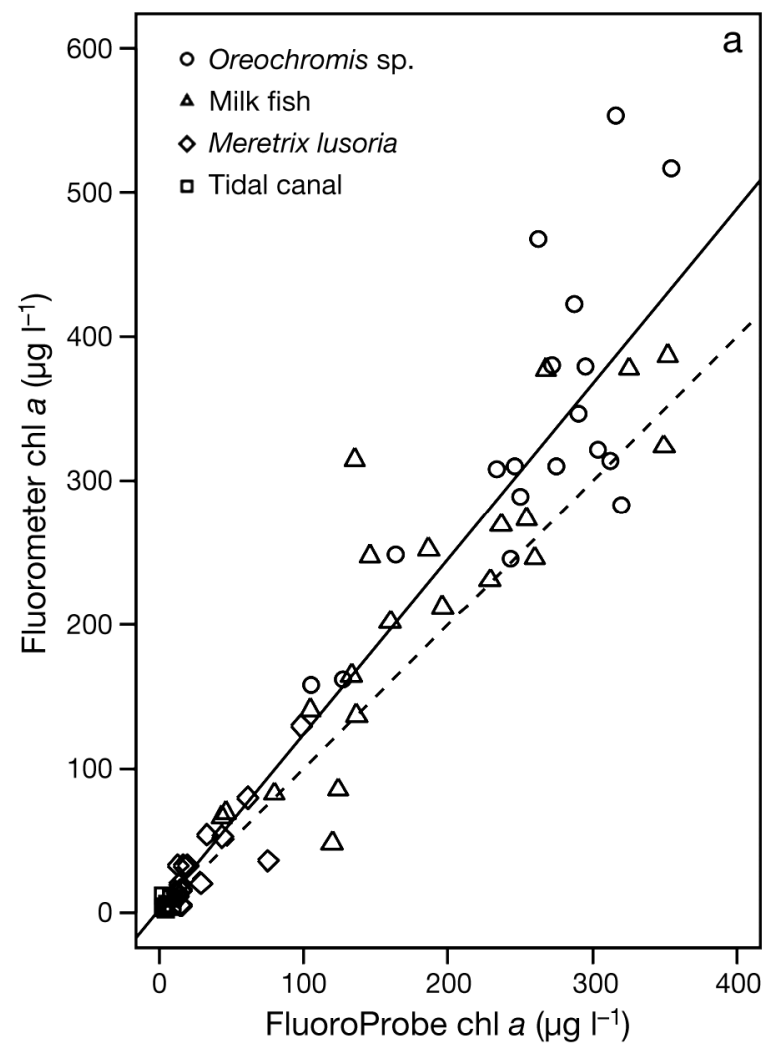

Fig. 2. Relationships between chlorophyll a ( $\mathrm{chl} a)$ measured by the FluoroProbe and: (a) chl a measured by the fluorometer, (b) algal density, and (c) algal biovolumes. Solid lines are regression lines; dashed line shows a 1:1 relationship

Probe and fluorometer $\left(y=7.339+0.308 x+0.302 x^{2}\right.$, $F_{2,60}=78.29, \mathrm{p}<0.001$, adjusted $\mathrm{R}^{2}=0.714 ; y=7.336$ $+0.349 x+0.258 x^{2}, F_{2,60}=72.71, p<0.001$, adjusted $\mathrm{R}^{2}=0.698$; respectively; Fig. 2c). Chl a:biovolume ratio (chl $a: B V$ ) was significantly different among samples dominated by different algal phyla $\left(F_{6,10.63}=\right.$ $37.61, \mathrm{p}<0.001)$. When cryptophytes dominated the

Table 2. Spearman correlation results between ranges of chlorophyll a $(\mathrm{chl}$ a) measured by the fluorometer and the FluoroProbe. ${ }^{*} \mathrm{p}<0.01$

\begin{tabular}{|cccc|}
\hline Ranges of chl $a\left(\mu \mathrm{g} \mathrm{l}^{-1}\right)$ & $\rho$ & $\mathrm{p}$ & $\mathrm{N}$ \\
\hline$<25$ & 0.600 & $0.008^{*}$ & 18 \\
$>25$ & 0.910 & $<0.001^{*}$ & 45 \\
$>50$ & 0.881 & $<0.001^{*}$ & 38 \\
$>100$ & 0.841 & $<0.001^{*}$ & 34 \\
$>150$ & 0.757 & $<0.001^{*}$ & 25 \\
$>200$ & 0.676 & $0.001^{*}$ & 22 \\
$>250$ & 0.382 & 0.144 & 16 \\
$>300$ & 0.429 & 0.337 & 7 \\
\hline
\end{tabular}
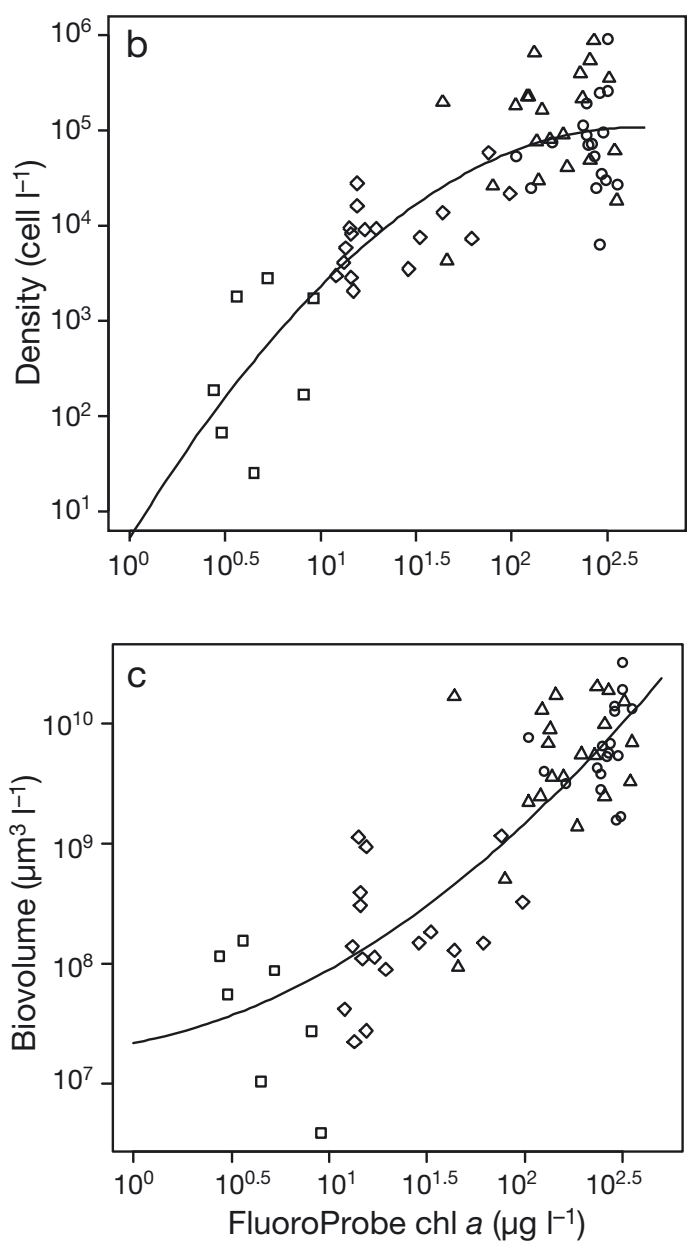

samples, they had the highest ratio, whereas samples dominated by other phyla had lower ratios.

The green group chl a measured by the FluoroProbe had a significant regression with biovolume $(y$ $=6.606-0.337 x+0.711 x^{2}, F_{2,60}=16.81, \mathrm{p}<0.001$, adjusted $\mathrm{R}^{2}=0.338$; Fig. $3 \mathrm{a}$ ). The chl $a$ of the blue group also had a significant regression with biovolume $\left(y=4.771+4.641 x-1.306 x^{2}, F_{2,60}=30.46\right.$, $\mathrm{p}<0.001$, adjusted $\mathrm{R}^{2}=0.496$; Fig. 3b). However, the chl a reads of the red and brown groups had nonsignificant regressions with their respective biovolumes $\left(F_{2,60}=1.90, \mathrm{p}=0.158\right.$, adjusted $\mathrm{R}^{2}=0.028$; $F_{2,60}=0.484, \mathrm{p}=0.235$, adjusted $\mathrm{R}^{2}=0.015$; respectively).

\section{DISCUSSION}

In this study chl a values measured by the FluoroProbe were related to those measured by the fluorometer in tilapia, milk fish, and clam aquaculture ponds, and all samples. Other studies found correla- 

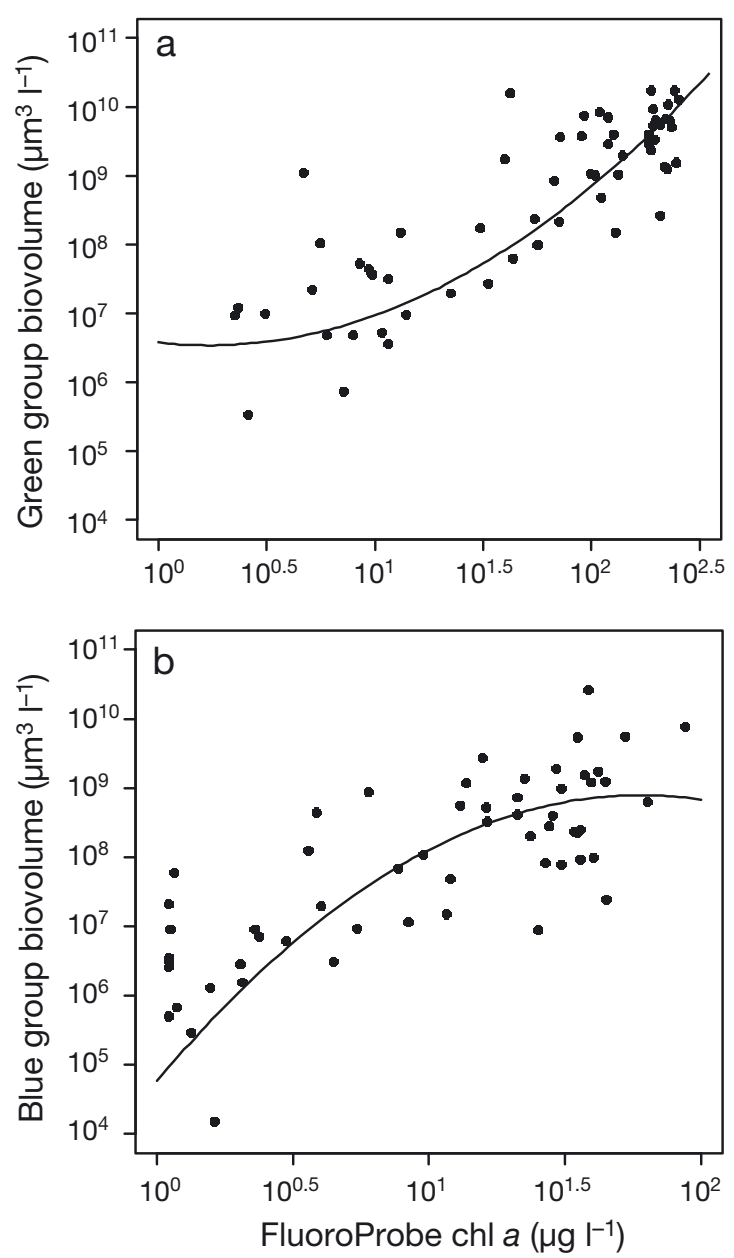

Fig. 3. Relationships between chlorophyll a ( $\mathrm{chl}$ a) measured by the FluoroProbe and respective biovolumes of (a) the green algal group (which includes chlorophytes and euglenophytes) and (b) the blue group (blue-green cyanobacteria). The fitted lines are regression lines

tions between chl a measured by the FluoroProbe and spectrophotometer in reservoirs (Leboulanger et al. 2002, Gregor \& Maršálek 2004, Gregor et al. 2005, Rolland et al. 2010). Fluorometers measure the emitted fluorescence, whereas spectrophotometers typically measure light absorbance (Pinckney et al. 1994). These 2 approaches may have differential bias in the same direction or bias in different directions of chl a measurements (Holm-Hansen et al. 1965, Pinckney et al. 1994, Dos Santos et. al. 2003). Thus, it may be more appropriate to compare the FluoroProbe to the fluorometer than to the spectrophotometer (Kring et al. 2014).

Our results confirmed that the chl a measurements by the fluorometer were higher than those by the FluoroProbe when chl a was $>200 \mu \mathrm{g} \mathrm{l}^{-1}$. Despite the same detection method, 3 factors may have contrib- uted to this difference. Firstly, chl a must be extracted prior to fluorometer measurements, while the FluoroProbe requires no processing of samples. Extraction can contribute to higher chl a measurements (Welschmeyer 1994). Secondly, tripton in pond water may block fluorescence emitted by algal cells. Thirdly, dense algal cells in water may block and scatter light emission by the cells, thereby reducing measurements of the FluoroProbe. The denser phytoplankton cells are, the higher is the proportion of blocking, scattering, and absorbance. The abovementioned mechanisms can also explain slightly reduced increases in chl a per biovolume at higher biovolumes indicated in Fig. 2c. High levels of colored dissolved organic matter (CDOM) may interfere with chl a readings of the FluoroProbe (Gregor \& Maršálek 2004, Rolland et al. 2010). However, CDOM was low in this study $(<10)$. Thus, this factor was excluded. Fluorescence quenching may contribute to reduced chl a readings (Leboulanger et al. 2002, Gregor \& Maršálek 2004, Rolland et al. 2010), but was likely not the case in the present study. Light extinction is generally high in aquaculture ponds because dense algae can block and absorb light in water. The sensor of our FluoroProbe was placed $50 \mathrm{~cm}$ below the water surface. For algae concentrated at the water surface (for light), fluorescence quenching may be reduced in this case. If strong fluorescence quenching occurred in this study, the differences in chl a between the FluoroProbe and fluorometer would be high at the lower end of chl $a$, which was not the case in the ponds studied here.

Based on correlations with fluorometer readings, the upper detection limit of the FluoroProbe was around $200 \mathrm{\mu g} \mathrm{l}^{-1}$ (bbeMoldaenke $\mathrm{GmbH}$ 2010). The statistical difference between the FluoroProbe and fluorometer was driven by higher chl a readings (>200 $\mu \mathrm{g} \mathrm{l}^{-1}$ ). However, Rolland et al. (2010) found no correlation above $21.6 \mu \mathrm{g} \mathrm{l}^{-1} \mathrm{chl}$ a between FluoroProbe and spectrophotometer in a 2 yr reservoir study. Gregor \& Maršálek (2004) found a nonlinear relationship above $50 \mu \mathrm{g} \mathrm{l^{-1 }}$ when colonial cyanobacteria were dominant in reservoirs. Chl $a$ in our study ponds ranged from 2.75 to $353.83 \mu \mathrm{g} \mathrm{l}^{-1}$, which was much higher than the chl a $\left(0.5-137 \mu \mathrm{g} \mathrm{l}^{-1}\right)$ measured in those reservoirs (Gregor \& Maršálek 2004, Rolland et al. 2010). The differential bias of the spectrophotometer and fluorometer may contribute to the nonlinearity observed at the lower range of chl a (Holm-Hansen et al. 1965, Pinckney et al. 1994).

The chl a measured by the FluoroProbe and algal density and biovolumes were related. Although some data points showed deviations from the regression 
lines, chl a by the FluoroProbe still could predict cell and biovolume densities, especially when chl a values were $<200 \mu \mathrm{g} \mathrm{l}^{-1}$. One possible explanation for deviations is that the chl a:BV (or density) ratio is different among the algal groups and also changes with environmental conditions (Rolland et al. 2010, Catherine et al. 2012). For example, non-overlapping small colonies of cyanobacteria with small cells may be measured by the FluoroProbe as having a high chl a content (Rodriguez et al. 1991, Rolland et al. 2010), whereas large, overlapping, dense colonies, such as those of Microcystis, may be measured as having low chl a content (Gregor et al. 2005, Catherine et al. 2012). Thus, the high biovolumes and low chl a content measured for the blue algae group may result from overlapping colonies of cyanobacteria. Euglenophyta in the green group also has a low chl a:BV ratio (Catherine et al. 2012). Algae in shaded conditions may show stimulated chl a production, thus having a higher chl a content (Langdon 1988). It is difficult to find a definite relationship between algal cell volumes and chl a content because cell size and chl a content are variable in different taxa (Catherine et al. 2012) and under different environmental conditions ( $\mathrm{Li}$ et al. 2000, Mas et al. 2008). This variability may contribute to the large variation in the chl $a$ and biovolume relationship.

High levels of cyanobacteria may serve as an indicator for critical water quality (Casé et al. 2008) since they can impart an 'earthy' off-flavor to aquacultural products (Zimba \& Grimm 2003) and might have toxic effects on cultured organisms (Zimba et al. 2001). Measurements of the red and blue groups by the FluoroProbe provide a rapid indication for cyanobacteria. However, dinoflagellates, which are important causes of harmful algal blooms in coastal and brackish water environments, are not separated from bacillariophytes and chrysophytes in the brown group by the FluoroProbe. If the FluoroProbe could further separate dinoflagellates, this could help to quickly detect this nuisance group in the coastal ponds.

The red and brown groups showed no significant correlations between biovolumes and the FluoroProbe measurements in our study. Several possible explanations are stated below. Cyanobacteria can be separated as either the blue or red group (Gregor et al. 2005), which may reduce the relationship with the overall cyanobacterial biovolumes, especially for the red group. Oscillatoria, small cyanobacteria, and N-fixing cyanobacteria with phycoerythrin may be classified by the FluoroProbe as belonging to the red group (Gregor et al. 2005, Catherine et al. 2012). When samples are fixed with Lugol's solution or formalin, dinoflagellates (brown group) may be misclassified as cryptophytes (red group; Rolland et al. 2010).

The FluoroProbe is applicable to common aquaculture conditions, but needs to be used with caution at higher chl a values $\left(>200 \mu \mathrm{g} \mathrm{l}^{-1}\right.$ ). The chl a levels from different aquaculture ponds showed distinct differences. Those with low chl $a_{1}$ such as the clam ponds (5.35-129.76 $\mu \mathrm{g} \mathrm{l}^{-1}$ ), could correctly be assessed by the FluoroProbe, whereas for those with high levels of chl $a$, such as the tilapia ponds (158.56-553.69 $\left.\mathrm{\mu g} \mathrm{l}^{-1}\right)$, the FluoroProbe can still be used with some considerations and adjustments. Critical levels of chl a for water quality management, selected by farmers, play a role in the usage of the FluoroProbe. If the critical level of chl a is $<200 \mu \mathrm{g} \mathrm{l}^{-1}$, the FluoroProbe can provide a reliable reading with no prior adjustments. If the critical level of chl $a$ is $>200 \mu \mathrm{g} \mathrm{l}^{-1}$, water samples with high chl a can be diluted at a known ratio and measured in a cuvette of the FluoroProbe Workstation 25 (a benchtop unit of the FluoroProbe). For example, in this study, we were able to detect high levels of chl $a$ in a clam pond using the FluoroProbe, which provided a warning sign for the farmer; this pond was subsequently harvested and cleaned.

The present study had several limitations. Firstly, the aquaculture ponds were brackish, as neither fully freshwater nor fully marine ponds were available for comparison. However, our samples spanned wide ranges of chl $a$ and environmental variables otherwise and represented a broad range of environmental conditions of aquaculture ponds. Secondly, we did not dilute samples for use in the FluoroProbe Workstation 25 when chl a was $>200 \mu \mathrm{g} \mathrm{l}^{-1}$ because Workstation 25 was not available during this study.

\section{CONCLUSIONS}

Phytoplankton management is a way to stabilize water quality for aquaculture ponds. Instant monitoring by measuring phytoplankton standing stocks is critical and becomes feasible by using the FluoroProbe. Our results showed that the FluoroProbe can indicate reliable chl a measurements $<200 \mu \mathrm{g} \mathrm{l}^{-1}$ when compared with a fluorometer. A lower range of phytoplankton density is desirable for certain aquaculture species, such as the common orient clam. When the acceptable phytoplankton level is higher, the FluoroProbe Workstation 25 is more applicable. This instrument can not only provide overall phytoplankton biomass levels but also differentiate be- 
tween different algal groups, which is useful for the assessment of critical algal condition. The FluoroProbe may provide practitioners like scientists, technicians, and farmers with detailed and reliable data for water quality management in terms of algal densities.

Acknowledgements. We thank Hua-Yu Wang for assisting with the field work. This study was partially supported by the Mariculture Research Center of the Fisheries Research Institute of Taiwan. H.U.D. acknowledges a grant from the Research Center for Environmental Medicine, Kaohsiung Medical University, Kaohsiung, Taiwan and the Asia-Pacific Ocean Research Center of the Department of Oceanography (No. 76211194) in the frame of the KMU/ NSYSU cooperation.

\section{LITERATURE CITED}

* Alonso-Rodríguez R, Páez-Osuna P (2003) Nutrients, phytoplankton and harmful algal blooms in shrimp ponds: a review with special reference to the situation in the Gulf of California. Aquaculture 219:317-336

Anand PSS, Kohli MPS, Roy SD, Sundaray JK and others (2013) Effect of dietary supplementation of periphyton on growth performance and digestive enzyme activities in Penaeus monodon. Aquaculture 392-395:59-68

bbeMoldaenke GmbH (2010) bbeFluoroprobe user manual, version 2.2 E2. bbeMoldaenke $\mathrm{GmbH}$, Kiel-Kronshagen

* Beutler M, Wiltshire KH, Meyer B, Moldaenke C and others (2002) A fluorometric method for the differentiation of algal populations in vivo and in situ. Photosynth Res 72 : 39-53

Carmelo RT (1997) Identifying marine phytoplankton. Academic Press, San Diego, CA

* Casé M, Leça EE, Leitão SN, Sant Anna EE, Schwamborn R, de Morales AT Jr (2008) Plankton community as an indicator of water quality in tropical shrimp culture ponds. Mar Pollut Bull 56:1343-1352

Catherine A, Escoffier N, Belhocine A, Nasri AB and others (2012) On the use of the FluoroProbe ${ }^{\circledR}$, a phytoplankton quantification method based on fluorescence excitation spectra for large-scale surveys of lakes and reservoirs. Water Res 46:1771-1784

Charles DF, Knowles C, Davis RS (eds) (2002) Protocols for the analysis of algal samples collected as part of the US Geological Survey National Water-Quality Assessment Program. Report No. 02-06. Patrick Center for Environmental Research, The Academy of Natural Sciences, Philadelphia, PA

Dahms HU (2014) The grand challenges in marine pollution research. Front Mar Sci 1:9

Ding YU, Li WC (1991) Common organisms in marine shrimp ponds. Council of Agriculture, Taipei

Dos Santos ACA, Calijuri MC, Moraes EM, Adorno MAT and others (2003) Comparison of three methods for chlorophyll determination: spectrophotometry and fluorimetry in samples containing pigment mixtures and spectrophotometry in samples with separate pigments through high performance liquid chromatography. Acta Limnol Bras 15:7-18

Ettoumi A, Khalloufi FE, Ghazali IE, Oudra B, Amrani A, Nasri H, Bouaïcha N (2011) Bioaccumulation of cyano- bacterial toxins in aquatic organisms and its consequences for public health. In: Kattel G (ed) Zooplankton and phytoplankton. Nova Science Publishers Inc., New York, NY, p 1-31

Field AP (2005) Discovering statistics using SPSS, 2nd edn. Sage Publications, London

* Florczyk M, Łakomiak A, Wo ny M, Paweł B (2014) Neurotoxicity of cyanobacterial toxins. Environ Biotechnol 10: $26-43$

F Furet JE, Benson-Evans K (1982) Evaluation of the time required to obtain complete sedimentation to fixed algal particles prior to enumeration. Br Phycol J 17:253-258

Green BW, Schrader KK (2015) Effect of stocking large channel catfish in a biofloc technology production system on production and incidence of common microbial off-flavor compounds. J Aquacult Res Dev 6:314

* Gregor J, Maršálek B (2004) Freshwater phytoplankton quantification by chlorophyll a: a comparative study of in vitro, in vivo and in situ methods. Water Res 38:517-522

* Gregor J, Geris R, Maršálek B, Hetesa J, Marvan B (2005) In situ quantification of phytoplankton in reservoirs using a submersible spectrofluorometer. Hydrobiologia 548:141-151

*Hemaiswarya S, Raja R, Kumar RR, Ganesan V, Anbazhagan C (2011) Microalgae: a sustainable feed source for aquaculture. World J Microbiol Biotechnol 27:1737-1746

*Hillebrand H, Dürselen CD, Kirschtel D, Pollingher U, Zohary $\mathrm{T}$ (1999) Biovolume calculation for pelagic and benthic microalgae. J Phycol 35:403-424

*Holm-Hansen O, Lorenzen CJ, Holmes RW, Strickland JDH (1965) Fluorometric determination of chlorophyll. J Cons Int Explor Mer 30:3-15

Hötzel G, Croome R (1999) A phytoplankton method manual for Australian freshwaters. Land and Water Resources Research and Development Corporation, Canberra

Hu B, Roy LA, Davis DA (2013) Correlations of xanthophylls in catfish fillets, plankton, shad and snails in catfish production ponds in west Alabama. Aquaculture 402-403: 46-49

* Kring SA, Figary SE, Boyer GL, Watson SB, Twiss MR (2014) Rapid in situ measures of phytoplankton communities using the bbe FluoroProbe: evaluation of spectral calibration, instrument intercompatibility, and performance range. Can J Fish Aquat Sci 71:1087-1095

* Kurten GL, Barkoh A (2016) Evaluation of community-level physiological profiling for monitoring microbial community function in aquaculture ponds. N Am J Aquacult 78: 34-44

Langdon C (1988) On the causes of interspecific differences in the growth-irradiance relationship for phytoplankton. II. A general review. J Plankton Res 10:1291-1312

Leboulanger C, Dorigo U, Jacquet S, Le Berre B, Paolini G, Humbert JF (2002) Application of a submersible spectrofluorometer for rapid monitoring of freshwater cyanobacterial blooms: a case study. Aquat Microb Ecol 30:83-89

Li A, Stoecker DK, Coats DW (2000) Mixotrophy in Gyrodinium galatheanum (Dinophyceae): grazing responses to light intensity and inorganic nutrients. J Phycol 36: 33-45

Li Y, Meseck SL, Dixon MS, Rose JM, Smith BC, Wikfors GH (2015) Short term effects of a commercial eastern oyster nursery upon nutrient and plankton dynamics of a coastal embayment: observations from mesocosm experiments. Aquacult Res 46:2049-2064

Mas S, Roy S, Blouin F, Mostajir B, Therriault J, Nozais C, 
Demers S (2008) Diel variations in optical properties of Imantonia rotunda (Haptophyceae) and Thalassiosira pseudonana (Bacillariophyceae) exposed to different irradiance levels. J Phycol 44:551-563

Mischke CC (2014) Winter pond fertilization can increase phytoplankton density in aquaculture ponds. N Am J Aquacult 76:67-71

Paerl HW, Tucker CS (1995) Ecology of blue green algae in aquaculture ponds. J World Aquacult Soc 26:109-131

Pinckney J, Papa R, Zingmark R (1994) Comparison of highperformance liquid chromatographic, spectrophotometric, and fluorometric methods for determining chlorophyll a concentrations in estuaries. J Microbiol Methods 19:59-66

Pucher J, Mayrhofer R, El Matbouli M, Focken U (2016) Effects of modified pond management on limnological parameters in small-scale aquaculture ponds in mountainous Northern Vietnam. Aquacult Res 47:56-70

R Core Team (2015) R: a language and environment for statistical computing. R Foundation for Statistical Computing, Vienna. www.r-project.org

Rodriguez H, Rivas J, Guerrero MG, Losada M (1991) Enhancement of phycobiliprotein production in nitrogen-fixing cyanobacteria. J Biotechnol 20:263-270

Rolland A, Rimet F, Jacquet S (2010) A 2-year survey of phytoplankton in the Marne Reservoir (France): a case study to validate the use of an in situ spectrofluorometer by comparison with algal taxonomy and chlorophyll a measurements. Knowl Manag Aquat Ecosyst 398:02

Editorial responsibility: Alejandro Buschmann, Puerto Montt, Chile
Smith JL, Boyer GL, Zimba PV (2008) A review of cyanobacterial odorous and bioactive metabolites: impacts and management alternatives in aquaculture. Aquaculture 280:5-20

Stevenson RJ (1984) Procedures for mounting algae in a syrup medium. Trans Am Microsc Soc 103:320-321

*Uddin MS, Azim ME, Wahab MA, Verdegem MCJ (2009) Effects of substrate addition and supplemental feeding on plankton composition and production in tilapia (Oreochromis niloticus) and freshwater prawn (Macrobrachium rosenbergii) polyculture. Aquaculture 297:99-105

*Welschmeyer NA (1994) Fluorometric analysis of chlorophyll $a$ in the presence of chlorophyll $b$ and pheopigments. Limnol Oceanogr 39:1985-1992

Yamagishi T (1992) Plankton algae in Taiwan (Formosa). Uchida Rokakuho, Tokyo

* Zhang X, Liu Z, Jeppesen E, Taylor WD, Rudstam LG (2016) Effects of benthic-feeding common carp and filter-feeding silver carp on benthic-pelagic coupling: implications for shallow lake management. Ecol Eng 88:256-264

Kimba PV, Grimm CC (2003) A synoptic survey of musty/ muddy odor metabolites and microcystin toxin occurrence and concentration in southeastern USA channel catfish (Ictalurus punctatus Ralfinesque [sic]) production ponds. Aquaculture 218:81-87

Zimba PV, Khoo L, Gaunt PS, Brittain S, Carmichael WW (2001) Confirmation of catfish, Ictalurus punctatus (Rafinesque), mortality from Microcystis toxins. J Fish Dis 24:41-47

Submitted: March 14, 2016; Accepted: November 14, 2016 Proofs received from author(s): December 18, 2016 